専門医症例報告

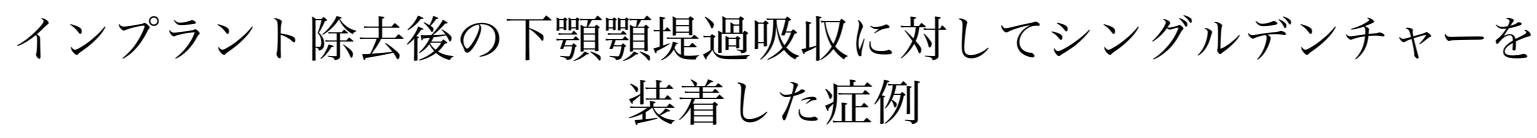

太田祥一

\title{
A Case of Single Denture with Severe Mandibular Residual Ridge Resorption after Removal of Dental Implants
}

\author{
Yoshikazu Ohta
}

\begin{abstract}
抄 録
症例の概要：下顎のインプラントと天然歯の連結ブリッジ除去後に全部床義歯を装着し調整を繰り返した が, 粘膜の疼痛が消退せず, 咀嚼障害を主訴に紹介受診した患者に対し，粘膜の被圧変位量の少ない顎堤 過吸収症例に透明レジンを用いた個人トレーによる印象法で全部床義歯を作製した。

考察：透明レジンを用いた個人トレーによる印象法は, 従来の選択的加圧印象に比べ, 粘膜の被圧変位量 の少ない部位を直視下にて緩圧するため，粘膜の疼痛の消退に効果的であったと考えた。

結論：粘膜の被圧変位量の少ない顎堤過吸収症例には，透明レジンを用いた個人トレーによる印象法が有 効であった。
\end{abstract}

和文キーワード

顎堤過吸収，緩圧，選択的加圧印象

\section{ABSTRACT}

Patient: After fixed partial dentures were removed with teeth extraction and placed dental implants removal in the mandible, a new complete denture was fabricated for the patient in another dental clinic. However, continous pain as he chewed gave him difficulty, and we fablicated a new complete denture with an impression technique using an individual tray made of clear resin to improve the difference of tissue displace-ability in my clinic.

Discussion: Because an impression technique of this kind is helpful to observe basal seat mucosa directly and to reduce high pressure on basal-seat mucosa, it is thought to be more effective in decreasing basal-seat mucosal pain in chewing than a traditional selective pressure impression would be.

Conclusion: An individual clear resin tray is effective in fabricating a complete denture with severe residual ridge resorption on the maxillae or mandibles, which have poor tissue displaceability.

\section{Key words}

severe residual ridge resorption, reduce high pressure, selective pressure impression

\section{I. 緒言}

近年，欠損補綴を行う際のインプラント治療は，歯科
医療の一つの選択肢として広く認知されている.しかし， インプラントを周囲炎などの原因により除去した場合, 当該部位には顎堤の過吸収が惹起され，その後の補綴処 置の難易度か増すことをしばしば経験する。今回，イン

東北・北海道支部（ウイズ・ユー歯科）

Tohoku-Hokkaido Branch (Dental Office With You)

受付: 2011 年 3 月 30 日/受理 : 2011 年 8 月 22 日

Received on March 30, 2011/Accepted on August 22, 2011 


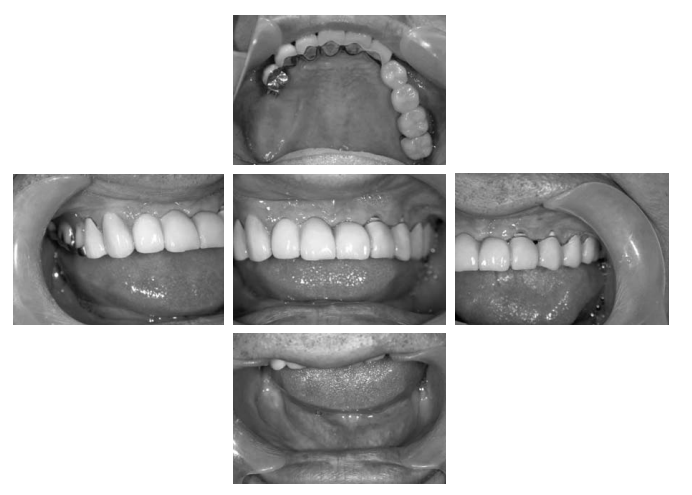

図 1 Intraoral views at the initial visit 初診時における口腔内写真

プラント除去後の下顎顎堤過吸収症例に対し，印象法に 考慮してシングルデンチャーを作製し良好な予後が得ら れたので報告する。

\section{II. 症例の概要}

\section{1. 症例（図 1)}

1）患者：69歳，男性.

2) 初診: 平成 13 年 6 月 22 日.

3）主訴：下顎全部床義歯を入れると痛くて咬めない.

4）現病歴： 2 年前に下顎のインプラントおよび天然 歯の連結ブリッジを除去し，全部床義歯を装着し調整を 繰り返したが粘膜の疼痛が消退せず，咀嚼障害を主訴と して紹介受診した。

5）既往歴：全身的な特記事項なし.

6）現症：口腔内所見としては，上顎に43|567残 存歯（すべて失活歯）と２１|l 124 相当部インプラン トのメタルボンドクラウンによる連結ブリッジが， 76 5にに歯冠外アタッチメントによる片側設計部分床義 歯が装着されていた。顎堤粘膜の触診により前歯部，左 側臼歯部および右側大臼歯部に被圧変位量の少ない部位 が認められた。歯周組織精密検査（図 2) の結果，ポケ ットが $4 \mathrm{~mm}$ 以上を示す歯は 2 のみであった。 また, X 線写真所見 (図 2) より, 上顎インプラント頸部周囲 には漏斗状の歯槽骨吸収像が認められ，下顎小臼歯相当 部の歯槽骨の過吸収が認められた。下顎顎堤は過吸収し ており，模型診査では特に左側小臼歯部は凹面となって いた。 下顎位および下顎運動の診査では，下顎位の水平 的偏位は認められず，旧義歯装着時の急速タッピング運 動でのタッピングポイントの収束性も認められた. 開口 障害はなく，顎関節症および顎機能異常の既往および症 状は認められなかった。腔習疴としては左側片咀嚼お よび日中のクレンチング辟を自覚していた。旧義歯所見 （図 3）としては，下顎全部床義歯は義歯床形態が小さく 不良で, 咬合高径が低く, 義歯床粘膜面の適合不良およ

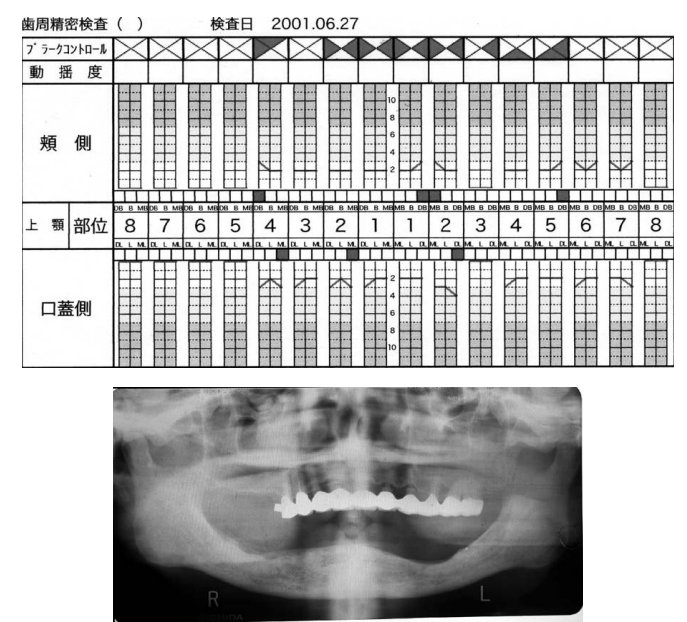

図 2 Examination of periodontal status Panoramic radiography at the initial visit 初診時における歯周組織検査とパノラマX 線写真

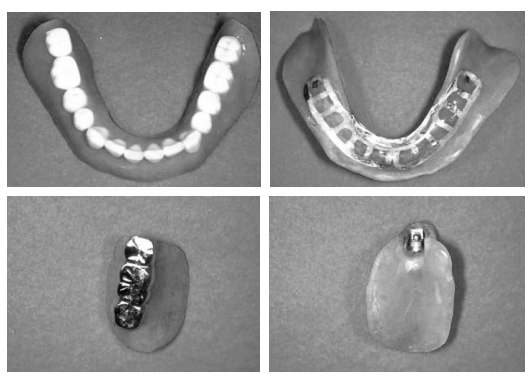

図 3 Initial dentures 旧義歯

び，義歯床研磨面形態の不良が認められた，上顎部分床 義歯は支台装置の連結強度が低いため，義歯の動摇が大 きく, 義歯床の適合不良のため支持性の不足が認められた。

2. 診断

下顎全部床義歯の不備による疼痛・咀嚼障害.

下顎無歯顎の症型分類は, 症型分類 1-1, level III（難 易度判定点数 47 点).

\section{3、治療方針}

下顎無歯顎に対しては, 全部床義歯およびインプラン トオーバーデンチャーを説明し，インプラントはもうや りたくないとのことで全部床義歯を選択した。作製にあ たつては, 粘膜の被圧変位量の少ない顎堤過吸収に対し ての印象法として，機能時の緩圧を目的に透明レジンを用 いた個人トレー (クリアトレー ${ }^{1-3)}$ ) を用いて行うことと した，上顎補経物は，本人希望により再治療ができなかっ たので, 咬合高径および咬合平面の設定に制約があった。

\section{III. 治療内容と経過}

\section{1. 下顎全部床義歯作製および調整方法}

個人トレーおよび辺縁形成用コンパウンド (ペリコン 

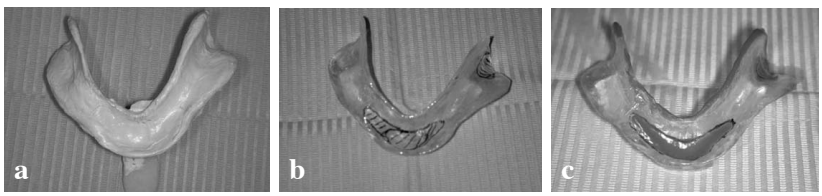

図 4 a: mucostatic impression, b: individual tray made of clear resin, c: final impression

$\mathrm{a}$ : 無圧印象，b：透明レジンを用いた個人トレー, c： 最終印象
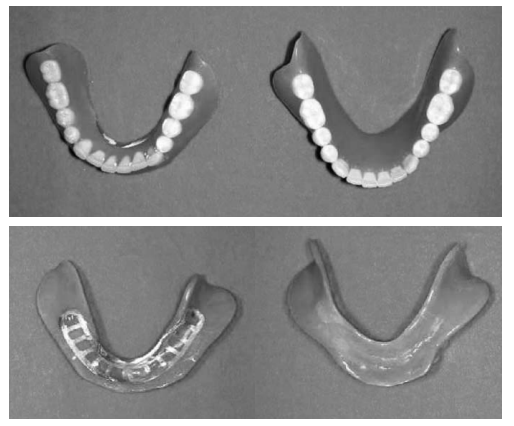

図 5 New denture (right) and initial denture (left) 新義歯（右）と旧義歯（左）

パウンド， G-C 社，東京，日本）を用いて筋圧形成を 行い, 無歯顎印象用印象材 (インプレッションペースト, G-C 社) にて無圧印象（図 4a）を行った。これにより 得られた作業模型にて最終義歯の床縁形態と同じ辺縁形 態を持つ個人トレーを流し込み法にて透明レジンを用い て精密に作製した。透明レジンを用いた個人トレーを試 適したうえで手指圧にて顎堤に圧接し，粘膜の被圧変位 量の少ない部位を印記（図 4b) し，削除リリーフ後，歯 科用インプレッションコンパウンド(イソコンパウンド, G-C 社）を用いて軟化・圧接を行う緩圧作業を繰り返 し行った。こうして得られた透明レジンを用いた個人ト レー内面を最終印象（図 4c）として石膏を注入し最終 的な作業模型を作製した。この作業模型上で咬合床を作 製し，咬合採得を行った。水平的下顎位はドーソンのバ イマニュピレーションテクニックにより決定し，垂直的下 顎位は Willis 法で決定し嚥下法にて確認した。 人工歯排 列に際しての人工歯選択は，下顎位が安定し，上顎補綴物 咬合面がポーセレンであることから，咬耗を考慮して陶歯 を選択して排列を行った，排列は咬合平面を義歯床後縁の 高さにまで挙上して咬合高径の回復を図ったが，顔貌所見 よりまだ低いと思われた。蝻義歯試啇の後完成し，平成 13 年 8 月 31 日に装着した(旧義歯との比較を図 5 に示す).

下顎全部床義歯装着と同時に，上顎部分床義歯の粘膜 部の支持性向上のためにリライン（直接法）を，咬合平 面是正のために人工歯部に金属アンレーを接着性レジン セメント（スーパーボンド, サンメディカル社, 滋賀, 日本）で接着し咬合調整を行った。咬合調整に際して,

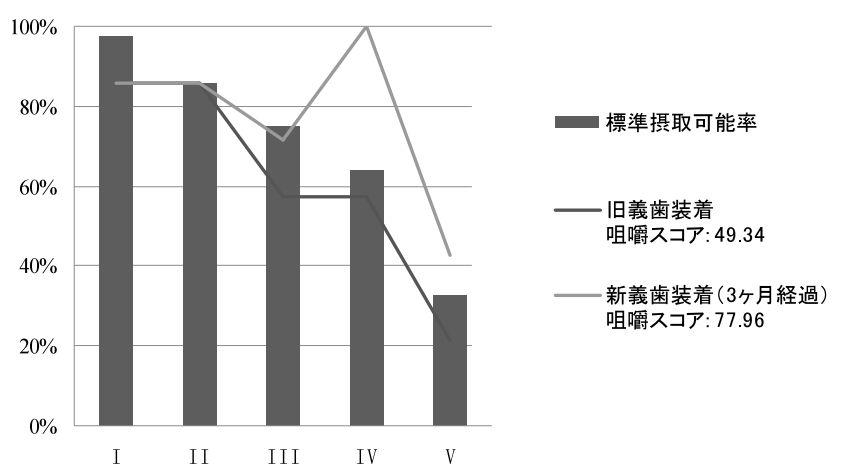

図 6 The capacity rate of food intake and the chewing score

食品摂取可能率と咀嚼スコア

上顎補綴物の咬合面の展開角が大きく機能咬頭咬頭頂が 不明膫であり，リンガライズドオクルージョンの付与は 困難であったことから，下顎人工歯㚘側咬頭頂が上顎咬 合面中心窩に接触する，いわゆる下顎バッカライズドオ クルージョンとし両側性平衡咬合を付与した.

\section{2. 下顎新義歯装着後の評価（図 6)}

患者は, 旧義歯と比較して咀嚼時の粘膜部疼痛はほと んど無く，何でも食べることができインプラント除去以 前の体重に戻ったと喜んでいた。 また平井ら ${ }^{4)}$ の摂食 可能食品アンケートを用いた全部床義歯装着者咀嚼機能 判定表による咀嚼機能スコアの結果も旧義歯より改善が みられ，好結果が得られた。

\section{3. 経過}

下顎全部床義歯に対しては, 数回の咬合調整を行った. 上顎インプラントおよび歯周疾患のメインテナンスのた めに，月 1 回の間隔でリコールを行いバイオフィルム の除去を行った。その際，咬合および粘膜部の疼痛の有 無や発赤等の診査も併せて行い，左側片咀嚼および日中 のクレンチング譬の是正を指導した。しかし，片咀嚼お よびクレンチング㾕の是正は十分には達成できず，この ため, 時折下顎左側顎堤陌包部粘膜の疼痛を訴元, 粘膜部 のリリーフおよび咬合調整を行つた。平成 16 年 10 月に 下顎左側粘膜面の適合不良および同部の咀嚼時疼痛に対応 するため, 軟性裏層材 (常温硬化型アクリル系弾性裏層材) を用いて直接法にて左側顎堤陥凹部の部分的なリラインを 行った。以後，平成 17 年 6 月，平成 18 年 4 月に同様に 下顎全部床義歯のリラインを行い，平成 18 年 7 月に上顎 部分床義歯に対して, 通常の裏層材（常温重合型アクリ ル系リライン材)を用いて直接法にてリラインを行った.

平成 18 年 11 月に下顎全部床義歯の人工歯の咬耗が 顕著になり，対合歯である上顎ポーセレンブリッジの咬 耗も生じていたため，これ以上の咬耗を防止する目的で 人工歯を硬質レジン歯とした下顎全部床義歯を新製する こととした。この間，最初の全部床義歯を装着して 5 


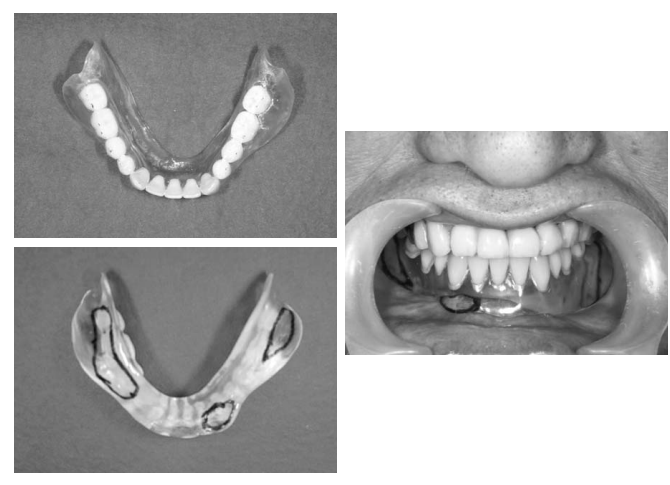

図 7 Pressure reduction of basal seat mucosa by a complete denture made of clear resin 義歯床部に透明レジンを用いた全部床義歯による義 歯床下粘膜の緩圧作業

年 2 カ月が経過したことになる。新製にあたり，まず これまでの義歯を利用して作業模型を作製し，この模型 を利用して流し込み法にて透明レジンを用いて透明な義 歯床を持つ全部床義歯を作製した．前回は緩圧作業を行 う際に手指圧により行ったが，今回は義歯床部に透明レ ジンを用いた全部床義歯の咬合調整を行つた後，実際の 機能圧に近い状態で行うことを考えて, 咬頭嵌合位にて クレンチングを行わせ，透明レジンを用いた個人トレー のときと同じように緩圧作業を行った（図 7).この後, 透明レジンを通常の床用レジンに改床し完成させ，平成 19 年 1 月に装着した。新製義歯（図 8）は患者からの 希望もあり当初から軟性裏装材（加熱重合型アクリル系 弾性リライン材）を粘膜面に貼付した状態とし，軟性裏 層材の貼付により義歯全体の剛性が低下するとの報告が あったので，床用レジン側に補強梁のある舌側板状の金 属床とした。 以後, 下顎左側顎堤陌凹部粘膜の疼痛の訴 えも減少し，経過良好で現在経過観察中である。

\section{IV. 考 察}

従来の選択的加圧印象は, 顎堤粘膜の触診によってス ペーサーの厚みや大きさを決定し, 顎堤粘膜に加わる圧 力をそれぞれの部位の圧負担能力に応じて調整して採得 されていたが，緩圧のためのスペーサーの厚みや大きさ は術者の触診により決定されるため, 術者の技量に左右 されたり，術者の主観によって左右されてしまうことが 多いが，今回の透明レジンを用いた個人トレーによる印 象採得法は，緩圧するべき部位を直視下にて診査し，粘 膜の被圧変位量に応じた緩圧効果が期待できることか ら，より客観的な手法と考えられた。また，義歯床部に 透明レジンを用いた全部床義歯での緩圧作業は, 透明レ ジンを用いた個人トレーによる印象採得法の欠点である

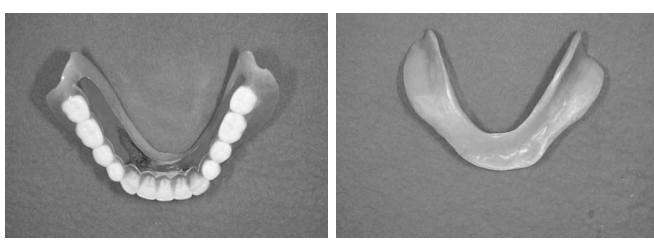

図 8 New metal-based denture with soft denture liner 軟性裏層材を用いた新製金属床義歯

粘膜に加わる圧をより機能時に近い咬合圧で行うことが できることから，より効果的であると考えられ，患者の 評価からも同じ結果を得ることができたと考えている。 こ の印象採得法は, 蛢義歯時の咬合圧印象と比較して, 義歯 床内面全体に印象材が介在しないために，より精度の高い 印象法と思われる. 反省点としては, 当初装着した義歯に 対合歯がポーセレンブリッジであったことに対して人工歯 に陶歯を選択し，上顎のポーセレンを咬耗させてしまった ことが挙げられる. 今後は硬質レジン歯の咬耗に対してリ モールをする時期を慎重に観察する必要があると考える.

\section{V. 結 論}

全部床義歯を作製するにあたり，義歯床下粘膜の被圧 変位量が少ない顎堤過吸収症例に対する印象採得法に は，透明レジンを用いた個人トレーを用いた方法は義歯 床下粘膜に対する適合の向上および被圧変位量の少ない 部分に対する緩圧作業ができることから疼痛緩和に有効 であると考えられた。 また，下顎位が安定し顎機能異常 がない場合には，義歯床部に透明レジンを用いた全部床 義歯を用いた緩圧作業は更に有効であると考えられた。

\section{文献}

1）諏訪兼治. システマチック総義歯印象法. Step 1. 総義 歯製作における印象の目的と操作原則。補綴臨床 2000; 33: 164-173.

2）諏訪兼治。システマチック総義歯印象法. Step 5. “ク リアトレー”による総義歯難症例への対応法と部分床義 歯への応用。補綴臨床 2000; 33: 654-670.

3）諏訪兼治，山内六男. クリアトレーを用いた粘膜の被圧 縮性を考慮した総義歯印象法. 補経誌 2001； 45 (105th Special Issue): 123.

4) 平井敏博, 安斎 隆, 金田 洌, 又井直也, 田中收, 池田和博ほか。摂取可能食品アンケートを用いた全部床 義歯装着者用咀嚼機能判定表の試作．補綴誌 1988; 32: 1261-1267.

著者連絡先：太田 祥一 T 005-0831 北海道札幌市南区中ノ沢 2 丁目 2 番地 REX $2 \mathrm{~F}$ Tel: 01 1-573-2588

Fax: 011-573-2589

E-mail: initial-y-88@sa8.gyao.ne.jp 